\title{
RECENZIÓ
}

\section{Foucault, még Foucault után}

\author{
Blandine Kriegel (2007): Michel Foucault ma. \\ Holnap Kiadó, Budapest. 93 p. \\ Takács Ádám (2018): Az idő nyomai. Michel Foucault \\ és a történelem problémája. Kijárat Kiadó, Budapest, 183 p.
}

\section{A. GERGELY ANDRÁS ${ }^{1}$}

Gyanús cím ez. Mintha elírták volna. Lehet valami/valaki önmaga, akár saját nemléte után? Ha a francia történész-filozófus-eszmetörténész-világértelmező 1984-ben elhunyt, lehet-e jelenléte hiányában is jelen lennie, avagy önmagához képesti ittlétével még (és nemcsak már) akár személyesen is úgy számolnia, mint a „távollévő nyoma” (Derrida fogalmi konstrukciója, a trace alapján) hitelesítette történéssel? Talány ez is, miként Foucault megannyi értelmezésmódjának túlélése a társadalmi gondolkodásban, s talány úgy is, miképpen lehetett erről fogalma magának a filozófusnak... De válaszai mégis vannak.

Foucault értelmiségi és tudománytörténeti közhely lett időközben, mindenhol idézhető etalon, s mert igen hatásos volt már éltében is, akkoriban sem pertraktálta másképp saját kora, mint struktúrákban, a jelentéstulajdonítás eszköztárában újdonatúj szempontot bevezető, a panoptikusság, az „átlátható” szervezettség, a felügyelt bűnösség analógiáját kínáló felfedezőt. Felfedezőt, avagy megnevezőt, akit sem a rendszabályozó társadalom, sem a jogképes értelmiség, sem a szociológiai konstrukciókra képes kritikai értelmezők, sem a kommunikatív világ nem tekinthetett immár másnak, mint az emberi jelenlét idői és történeti folyamatosságát vitathatónak mondó provokátornak, vagy a mindenkori hatalom megrögzötten kíméletlen kritikusának. Már életében is múlt volt önmagának, s már akkor is egyben a jövő kérdéseit szétfeszegető másként gondoló maradt a tudáspiacon, miközben ugyanitt főhatalommá erősödött. A Foucault-kutatók azután már sokszor épp a Foucault traktálta állapotokat tükrözik, kezdve azoktól (például Kiss Balázstól vagy Szakolczai Árpádtól), akik a „Foucault még Foucault előtt” szempontját vezették be életmű-elemző írásaikban (Kiss, 1994, 1997; Szakolczay 1990), és zárva a sort azokkal, akik a Foucault-hatást már nemcsak az utókori válaszok felől tekintik (ekként például Derrida is, pl. 1978), hanem a még életében kiterjedő megértésmódok sokfélesége alapján konstruálják meg teljesebb értékelését (vö. Zizek 2007). Ezekhez képest lenne ér-

${ }^{1}$ ELTE TÁTK Kulturális Antropológia Tanszék, e-mail: andrasgergelya@gmail.com 


\section{RECENZIÓ}

telmezési nóvum annak feltárása, miképpen reflektál önmagára a filozófus a mindegyre erőteljesebb hatások konstatálása, saját korjelentőségének elismertetése körében. Ekképpen a jelenlét hiánya épp a hiány jelenével gazdagodik: az önértelmező olvasatok során át, a föl nem tett kérdéseken túlra ível mindmáig a Foucault-utáni gondolkodásmódok még Foucault-val és múvével egybeértendő teljessége. S ehhez illeszkedik, ezekből fogan mintegy a jelenlét-örvény is, melyet az értelmező világ a folytonosság révén állandósít.

E felhangoló entrée nyomán már szinte kívánkozik az ismertető rovatba ajánlott mú, mely ezúttal nem egy, hanem mindjárt kettő, párhuzamosságaikkal és eltéréseikkel egyszersmind húsz és negyven év távolából rápillantva a filozófus-történész munkásságára. No de miért is érdemesítjük ezeket, mikor még az eredeti Foucault-műveket sem olvastuk szétesetté? Mit hoz, mit ad a másodolvasat, a bevezető tálalás, az áttekintő bölcselem arról, amit keresnénk, amit problematikusnak - vagy épp csak aktuálisan sajátnak - tekintünk mostanság, amit (már és még) Foucault idejében is annak láttak az elfogadó vagy támadó értelmezések? Erre keresek két részválaszt alább, két monográfia ürügyén.

Ismeretes, hogy Foucault-t a XX. század egyik legnagyobb hatású gondolkodójának tartják, s már akkor is az volt Derridával, Deleuze-zel vagy Lyotard-ral együtt akik viszont „csak” filozófusnak mutatkoztak, nem pedig keverten filozófiai érvényú szociológusnak és uralom- vagy önuralom-történésznek is ráadásképpen. Foucault életművében vezető szálként mutatható ki a hatalmi mechanizmusok, eljárások, packázások, erőszakok és mikromechanizmusok kitartó, sőt elszánt elemzése. Nagy vonalakban erre épít Blandine Kriegel filozófiaprofesszor is, aki Párizsban a 70-es évektől tíz évig volt Foucault asszisztense a párizsi Collège de France-ban, s aki így nem csupán életmúvét ismeri, de személyét, jellemét, $A$ szavak és a dolgok vagy a Bolondság története sikerkötetek hátterét is. A filozofikus mélységű gondolkodás- és viselkedéstörténeti háttérről, a mikroszkopikus árnyaltságú szexualitás-, őrületvagy börtöntörténeti totálképből azonban még nem okvetlenül sejlik föl a filozófus mint filozófus, a Foucault mint Foucault-értelmező, a mindennapi szakmai vitái közben résztvevő érvelő, a „kitaszítottak és felügyeltek” körébe sorolódó társadalomkutató, a hatalmi mechanizmusokat a hatalom spektrumából láttatni képes megfigyelő. Kriegel könyve főhőse körül három esszéforma előadásmódot formál: Foucault tegnap, Foucault mint filozófus-művész-politikus, valamint Foucault ma - avagy mindezzel a „mi marad az életműből?” kérdéssel a stílust, a csapongást, a tartózkodó eleganciát, a fegyenc keménységét a sportoló teljesítményével kiegészítő munkabírást fölidézve, amely magyarul is végre megjelent. Kriegel alapkérdése mindvégig a kortárs Foucault társadalmi intézményekben és uralmi rendek változatos sodrában kialakult rendszerét átlátni próbáló, már a művek hatásreményét is előlegező bizonyosságkeresését tükrözi. Szerinte a filozófus alapkérdése a „mit jelent élni és embernek lenni a XX. század végén?" volt, s válaszaira minduntalan a visszakérdezést tekintette evidens eljárásnak. Kriegel tónusválasza is erre emlékeztet: „Azért 


\section{RECENZIÓ}

távolodtunk el annyira az életétől és a művétől, mert általában eltávolodtunk a csodálat és az elismerés képességétől. Végső soron mit is kellene csodálnunk az eredeti gondolkodást üldöző kollektív ideológiákban? Mit kellene csodálnunk a tehetségtelen bürokraták és múveket létrehozni képtelen testületek által ma a korábbinál még inkább gyarmatosított egyetemeinken? Mit kellene csodálnunk a szerzett jogok konzervatív és unalomig nyomatékosított védelmében?" (Kriegel 2007: 90). S a kötet (hangsúlyosan a Foucault ma fejezet) arra figyelmeztet, hogy az időbeli „ma” még a tegnap, a Foucault művét és személyét lázadónak tekintő kortárs gondolkodásmód idején indul, s épp az értelmező nagyság, az elemző tisztaság, az evidens belátások képviselőjét tekinti az elnyomásra ítéltek egyikének, problematikáit a francia kommunisták évi rendes ünnepén vörös sipkával már nem koronázható ellentmondás alapjának, a beszéd erejét rehabilitáló gondolkodó személyét pedig akadálynak, melyet a „térdre, imához!” tónusában próbálhat leküzdeni a korszellem, de ez esetben sikertelenül teszi (Kriegel 2007: 90-91). Egyik jele annak, hogy Foucault még Foucault után sem marad megtagadhatatlan, s egyúttal annak is, hogy már létében is az volt egyesek számára.

Kriegel első fejezete tehát a Foucault-befogadás tegnapjából indít, hogy a lehetséges értelmezések érdemes holnapját sugallja. Már kötete első oldalán szerepel a Bolondság történetét vitató orvosok és pszichoanalitikusok fejcsóválása, az esztétikai elemzéseit követő mormogás, a humán tudományok „hard filozófiával” értelmezése alkalmával a nyelvészeti és antropológiai aspektust idéző érvelés, melynek elutasításával további tudományos körök vettek bátorságot Foucault bírálatára, sőt a „strukturált tudattalan” téves felfogásával szembeni idegenkedésként fogadták szemléletmódját is, a metafizika eredendő káosza ellen fellépő gondolkodó elutasításával pedig „a polgárjogot nyert elsődleges filozófia” oldaláról vettek elégtételt rajta. A „rend és modell kísérlete” mint a korabeli filozófia új harsonaszavának dicsősége Foucault számára „a tudás archeológiája” alapján újraértelmezendő irány kételkedő átgondolása volt ebből a kiút: „a sartre-i egzisztencializmus tétova, reszketeg kezéből kivette Heideggert, hogy levonjon belőle minden következtetést, és végigjárja ezt az utat” (lásd az Althusser-csapást, mely „minden humán tudományt összeegyeztethetővé tett a marxizmussal, és ezt megint korunk aktuális filozófiájává emelte... A struktúra filozófiájává, amelyben a szubjektum támpont csupán, termelési mód, amely a struktúra elfogadható modelljét állítja elő - ebben pedig az egyének mindig csak hiányuknak köszönhetően léteznek") - s ebből így marad ki a kérdés, hogy „az ember mássága” miként vezet „az etnológia és a pszichoanalízis vitathatatlan uralmához”, a végesség felfedezéséhez, „,a tengerparti fövenybe rajzolt arc” megmaradásához (Kriegel 2007: 9-10).

A kötet második „fejezete” az esszéfohász és a tudományos hősmemoár partvonalai közötti, a roppant személyes és megtisztelnivalóan mélyértelmű tudományos életút-részletek, érdemi értékelés és korrekt szakmatörténeti elhelyezés megtestesülése (Kriegel 2007: 17-75). Ezt is három részre tagoló aspektusban: Foucault a 


\section{RECENZIÓ}

filozófus, a művész, a politikus tagolásban ad kellő árnyaltságú, közelségű és hiteles leírást a múegész szerkezeti képéről, rendszeréről, környezetéről és részben fogadtatásáról is. Ehhez illő intimitás-invokációként a Mestertől idéz a blokk elején, ami mintegy feladattudat és vállalás, struktúra és emberkép szempontjából is karakterizálja a várható tartalmat: „Már régóta tudjuk, hogy a filozófia szerepe nem abban áll, hogy fölfedje, ami rejtve van, hanem olvashatóvá tegye, ami látható, vagyis megjelenítse a nagyon közelit, a nagyonis közvetlen dolgokat, amelyek olyan bensőséggel kötődnek hozzánk, hogy nem is észleljük őket." (Kriegel 2007: 16) Vagyis itt A klinikai gondolkodás születése. Elmebetegség és pszichológia témakörrel indítva valahol a szavak és dolgok mibenlétének, a látásra redukált belátás strukturalizmusokon túli esélyeinek, az ábrázolás mindenkori episztémét meghaladó, modellező hajlandóság mögötti látásmódját emeli ki, ennek fenomenológiai elemeit és a történelem látása felé tolódó komplexitását sem kímélve. Majd a múvészet iránti érdeklődés és a teremtés mint perspektíva szempontjai jönnek, Foucault-val szólva: „Egyfajta történeti fikciót építek. Bizonyos mértékig nagyon jól tudom, hogy nem igaz, amit mondok... Abban reménykedem, hogy könyveim megírásuk után változnak igazsággá." (Kriegel 2007: 31) A harmadik tematika hívószava a képzelet és álom kontextusában is a lehetőség a másságra: „Mivel a létezés boldogtalansága mindig az elidegenedésben gyökerezik, a boldogság pedig, empirikus szinten, nem lehet egyéb, mint a kifejezés boldogsága." (Kriegel 2007: 53) S amit ebből a Nyelv a végtelenhez magyar kiadásában is döntő választóvonalként mutat be a megismerés képi és dologi, mozgás és megjelenítés együttes tükröződésében hangot nyerő verzióiként, az visszautal $A$ szavak és a dolgok, valamint a későbbi A tudás akarása művekhez. ${ }^{2} \mathrm{~A}$ záró előadásfejezet a politikus Foucault megidézése (Kriegel 2007: 55-75), körülményeivel, a modern politikai filozófia „pásztori politikának" beillő természetével, a csatazajban is „a társadalmat meg kell védeni” kötelezettség nevében, a francia ismeretelméleti iskola forrásainak és a brit moralistáknak illő elismerés mentén, de a biopolitika bűnét folyamatosan opponáló attitűddel élés kötelezettségét is ide véve mint vállalt feladattudatot (Kriegel 2007: 60-68).

Kriegel harmadik fejezete a fennebb idézett, „a ma nevében” opponáló felfogás eredőit mutatja meg Foucault ellenzéke, támadói, majd melléje állt hívek körében: a mindig mindent újragondolni próbáló érzékeny lény, aki (nem úgy, mint Althusser vagy Lacan, akik színpadias szigoruk és szertartásaik, híveik megszervezésében „régi vallásukra és dogmáikra, kolostori szervezeteikre és zárdaszabályzataikra támaszkodtak”) mágikus gyorsasággal utasítja-távolítja el a „foucault-i gondolkodásmód" esélyének megjelenését is, a reá támaszkodó kultuszformálási szándékot, de kisugárzásából az a szabadságigény árad, melyet mindenkivel kíván megosztani, s nemcsak a kiváltságosokkal. Ennek méltósága rejlik például abban, hogy „halálosan utálta a kommunista rendszert", az iskolássá tett szellemet, a bürokratikus tudat-

${ }^{2}$ Nem szabadna feledni Romhányi Török Gábor érzékletes fordítását ez esetben is, mint korábban számos Foucault-mű kiváló interpretálásában. 


\section{RECENZIÓ}

lanságot, a szektáktól szétforgácsolt és tönkresilányított eszméket, az ideológussá csiszolt kutatókat és a propagandistává züllesztett értelmiséget (Kriegel 2007: 84-87). Rokonszenve a lázadásé volt, a lengyelek szolidaritási mozgalmáé, a tervgazdálkodásba fulladt „permanens forradalom” elvitatóié, a marxizmust „fukóizáló” bűvészmestereket viszont kellőképp le is kezelte, a pszichoanalitikai elköteleződéseket tűrés-szinten kezelte, miközben a „változatlan emberi természetben” valami transzcendens viselkedés normativitását visszaidéző kortárs felfogásokkal sem volt meg békében. Talán ugyancsak ezért, záró szavaiban Kriegel épp e megértő mód lehetségességét hangsúlyozza a ma tegnapjában, a Foucault utáni Foucault teljesebb életmü-értékelésében.

\section{Az idő nyomvonalán, a történelem problémája körül}

A követők, vagy akár csak kedvelők, olvasók, értelmezők hazai szaktudományi területekre sem restelnek súlyos műegész-részleteket, szövegfoszlányokat átemelni. A máig szólóan „aktuálisnak” tekintett Foucault életmúve talán a metodológiai színtéren némi fenntartásokkal kezeltnek mondható (árnyalhatnánk úgy: senki sem követte azóta sem az Én, Pierre Rivière szemléleti-metodológiai komplexitását például...), de gondolkodásának hagyatéka nem hagy kétséget afelől, hogy Habermas vagy mások kritikai észrevételeivel akár egyet is lehet érteni, sőt kell is vitatkozni velük (akár Jean Baudrillard javaslatával ellentétben), de semmiképp sem lehet „múlt időnek tekintve" összegző visszatekintést adni. Már csak azért sem, mert az olvasatok olvasatai is kezdenek alkönyvtárba rendeződni, s egyre megkerülhetetlenebb lesz az újabb felfedezések, összegzések kísértései felé elindulni.

Egy ilyen kísértő indulás lenyomata Takács Ádám: Az idő nyomai. Michel Foucault és a történelem problémája című monográfiája, aki rögtön bevezető soraiban már utal a fenntebbi véleménykorszak felhajtóerőire: „A filozófusok közössége aligha az a hely, ahol Michel Foucault művének legelhivatottabb követőire bukkanhatunk. Jó esély van viszont arra, hogy legádázabb ellenfeleit a társadalomtudósok, és közelebbről a történészek között leljük fel. Ennek a furcsa helyzetnek, és a mögötte rejlő dilemmának a tisztázása volt e kötet elemzéseinek motivációja. Foucault múve ugyanis kétségkívül a 20. század legerőteljesebb és leginspirálóbb intellektuális vállalkozásai közé tartozik. A filozófia területén túl, alapvető hatást gyakorolt a történetírás, a szociológia, a kultúra- és irodalomtudomány, az antropológia, a gender studies és megannyi más területre. Ugyanakkor talán épp emiatt annak tisztázásában, hogy miben is áll a foucault-i vállalkozás jelentősége, nehéz egyértelmű közös pontokat találni az említett diszciplínák megközelítéseiben." (Takács 2018: 7) ${ }^{3}$

${ }^{3}$ Foucault szövegidézetek - a kiadó jóvoltából - innen: https://www.academia.edu/36514494/ Az_id\%C5\%91_nyomai._Michel_Foucault_\%C3\%A9s_a_t $\%$ C3\%B6rt\%C3\%A9nelem_probl\%C3\%A9m\% C3\%A1ja 


\section{RECENZIÓ}

A Szerző itt magyarázkodó-értelmező szabadkozással kezdi rendszerleíró kötetét: mivel Foucault életműve - jóllehet kötetei leginkább „történelmeket” közelítenek meg komplex szempontból, úgymint a bolondság, az őrület, a börtön, a szexualitás, a kórház, a bölcselet stb. -, mégis sokkal inkább a filozófiai feldolgozottság felé hajlik, s ezen belül is politikai konnotációkba fordul (úgymint a tudás, a büntetés, a hatalom, a szubjektivitás stb.), s ezek mint mozgó keretek nehezítik filozófiája áttetszőbben strukturált leírását. Ezért is a kötet a Foucault-optikára jellemző heurisztikus ráközelítések, áttetsző horizontok, az „idő nyomainak” kérdései, s ezek tükröződései mentén indul Foucault munkásságát a „rámenős egységesítéstől” eltérő kérdések erezete mentén igyekezve feltérképezni és bemutatni. ${ }^{4}$

E kötet alaptézise mégis az, hogy nem lehetetlen Foucault munkásságát egyetlen problémakör keretében megragadni. E lehetőség kidolgozása festi fel az elvégzett elemzések konkrét horizontját. Átlátásom szerint nem Foucault különböző korszakainak és eljárásainak „rámenős egységesítéséről” van szó, hanem - némiképp Foucault eljárásaihoz híven - épp azoknak a motivációknak, elméleti belátásoknak és gyakorlati szabályoknak történeti leképeződését megértő szándékról, melyek történészi-filozófiai gyakorlatának szinte állandó jelenségei. Foucault ugyanis a történelem kérdésében megbúvó történetértelmezési és filozófiai téteket leggyakrabban úgy kalibrálja át, hogy a jelen-múlt viszony úffajta artikulálódása lesz az eredmény, mely sokak olvasatában megakasztja a történeti időfolytonosság konvencionális eljárásait, vagy „a történeti módon való létezés kérdésének radikálisan új megfogalmazásához" vezet, miközben episztemológiai beállítódását is tükrözi. Az első rész első fejezetében (Takács 2018: 14-123) Takács arra törekszik, hogy megjelenítse: a megélt és gondolt jelen, az archeológia és geológia múltképe vagy tapasztalata miként változik az idők nyomainak képzetei révén az „elgondolt múlt” és a történetírás tárgyaként megjelenő tematikák rendszerévé, ezen belül is hogyan lesz diszkurzív formációkká vagy hatalmi viszonyrendszerek tükrözőjévé. Így jut arra, hogy a „múlt kijelölésében” és „a történelem mint aktivitás” interpretálásában nem (tisztán) valami „általános történelem”, „kijelölt múlt” természetesnek vett értelmezésében juthatunk előbbre, hanem (mint írja): a tradicionális felosztások ellenében egy-egy „adott probléma-meghatározás alatt itt azokat a témákat kell értenünk (őrület, kli-

${ }^{4}$ A hivatkozott forrástanulmányok, melyekre a kötet összegzései, fejezetei is épülnek: Michel Foucault és a történelem tapasztalata. Századvég, 1998/3: 143-146; Történeti megismerés és történeti tudás Michel Foucault-nál. In: Szekeres A. (szerk.) (2002): A történész szerszámosládája. A jelenkori történeti gondolkodás néhány aspektusa. L’Harmattan Kiadó, Budapest, 15-35; Szubjektivitás és szubjektiváció: Foucault egzisztenciális modelljei. Pro Philosophia Füzetek, (36), 2003:11-18; A történelem ereje: módszer és tematika Michel Foucault-nál. Zempléni Múzsa, 2005/3: 18-28; Foucault problematikája és a drogkérdés. In: Rácz J. - Takács Á. (szerk.) (2006): Drogpolitika, hatalomgyakorlás és társadalmi közeg. Elemzések foucault-i perspektívából. L’Harmattan Kiadó, Budapest, 22-45; Az elfelejthetetlen Michel Foucault. Magyar Szemle, 2006/3-4: 139-145; Biopolitika és nemzeti állapot: egy foucault-i problematika rekonstrukciója. In: Cieger A. (szerk.) (2009): Kötőerők. Az identitás történetének térbeli keretei. Atelier, Budapest, 15-28. 


\section{RECENZIÓ}

nika, börtön, test, szexualitás, szubjektivitás), melyeket Foucault történelmi tárgyakká alakítva, a jelen diagnózisára és filozófiai kritikájára való tekintettel, történetileg vizsgálat alá von" (Takács 2018: 95). A filozófiai és történeti modellalkotás itt egy „foucault-i egzisztencializmus” révén kerül át a szubjektivitás történeti modelljeibe, ami „saját létezésünk bizonytalanság-evidenciáinak megalkotását jelenti: normalitásunkét, megismerésünkét, igazságainkét, testünkét, társadalmi-közösségi gyakorlatainkét" - ami semmivel sem kevesebb filozófiai elmemunkát kíván, mint bármely hagyományos eljárás, melynek nevében a filozófia megnyilatkozni volt hivatott (Takács 2018: 123).

Takács hangsúlyozza: „Foucault kutatásait minden esetben egy aktuális jelenség problematizálása motiválja, mely azonban a kutatást arra készteti, hogy e jelenség analízisét történetileg, azaz a múlt nyomaira való tekintettel végezze el. Az eljárás eredményeképpen egy olyan beállítódás jön létre, melynek következtében a 'múlt' hagyományos fogalma átalakul, és ebből lehetőség nyílik a jelen kritikai analízisére”. Ezért is veszi párhuzamba egyfelől Foucault új történeti beállítódása számára meghatározó jegyek sorát (nevezetesen a történelem tárgyának megváltozását, vagy azt, hogy a történeti kutatás tárgyául nem tények, események vagy másfajta adottságok, hanem viszonyok jelenléte és hatása kérdései szolgálnak, egyebek között az Annales iskola sokszor hasonló törekvései, valamint a történelem tárgyának átalakításából fakadó történészi gyakorlat következményei is), hogy azután másfelől a második rész három további fejezetében a sajátos történészi eljárás olyan aktív kutatási gyakorlatként jelenhessen meg, „amely egyaránt szakít a történeti múlt empirista és idealista felfogásával. Ez a konstruktív történészi praxis a források újfajta kezelésében, a periodizáció új formáinak bevezetésében, és egy erőteljes elméleti-filozófiai fogalmi apparátus alkalmazásában áll”, ezek tanulságaiból fakadó olyan történeti modellálást lehet így követni, „mely képes az emberi létezés általában vett társadalmi-tapasztalati állapotának megvilágítására” (Takács 2018: 9). Így a „jelen történetének” kutatási programja egy ontológia körvonalait hordja magában, „amely azonban nem a lét és létező kategoriális vagy fenomenológiai elemzésén, hanem az emberi létezés történetileg konkrét módon adott lehetőségeinek számbavételén alapul”. A „gyakorlati filozófia” címszava Foucault módszereinek, kutatási témáinak és alapvető fogalmainak alkalmazhatóságát teszteli: az első fejezet átfogó áttekintésben ad számot módszerek és tematikák összhangjáról a foucault-i életmúben, kiváltképp a tudás, a hatalom és a szubjektivitás témakörei mentén, beleértve a foucault-i gondolkodás flexibilitását és kritikai hatékonyságát is. Majd a második és harmadik fejezetben olyan területeken kíséreli meg a foucault-i elemzési stratégia és fogalmiság „gyakorlati” alkalmazását, mint példaképpen a „biopolitikai” tematika és kiterjesztése a nemzet, nemzeti azonosság jelenségeivel meghatározható területre, hogy záró fejezetében Foucault szempontjait ismertesse a modern európai illegális droghasználattal összefüggő társadalmi képzetek és gyakorlatok terén, ide értve az elemző és 


\section{RECENZIÓ}

a kritikai problematikát is (pl. a drog pillanatai szemben a hatalom mintázataival, a képzelet és az öröm dimenziója, az anyag hatalma és a kontroll radikális dilemmái, a társadalmi egészség biohatalmi beavatkozással támogatott totális kontrollja - az „államilag támogatott rasszizmus" -, valamint a pszichoaktív társadalmiság szubjektivizációs technikákkal befolyásoltsága, a kockázatvállalás modernitásban átalakult normái stb.). Mindezekkel „nem Foucault különböző korszakainak és eljárásainak rámenős egységesítéseiről” kíván szólni, „hanem - némiképp Foucault eljárásaihoz híven - azoknak a motivációknak, elméleti belátásoknak és gyakorlati szabályoknak az egységes figyelembevételéről, melyek Foucault történetfilozófiai praxisának legtöbb pontján felismerhetőek" (Takács 2018: 8).

Takács a konklúziót tartalmazó utóhangban egy hangsúlyos kontraszttal él bevezetésként: Baudrillard egy 1977-es könyvének címével (Felejtsük el Foucault!) nemcsak azt provokálta, hogy a kor addigra már legnépszerűbb francia filozófusa még növelje is hívei táborát és keresettségét, de a Collège de France-on megtartott (addig publikálatlan) előadásainak kiadása is érzékeltette, hogy az életművében leghangsúlyosabb témakörei - így a tudás és hatalom változatai az állam, a nemzet, a liberalizmus vagy a rasszizmus - mintegy összegző újratárgyalásával valamiféle tartósítást kaptak, mégpedig mindmáig érvényes üzenetekkel, melyek a filozófia folyamatos változásának is jelzői lettek az érdeklődésváltozás lenyomatai révén. Kiderült ezekből, hogy a korabeli „strukturalizmusból” önként kimaradni szándékozó Foucault ezzel mintegy „megúszta” az irányzat gyors értékvesztésével járó tudományos krízist, majd hatása „poszt-strukturalizmus” címén terjedt el a tengerentúli tudományos világban, amihez persze a marxizmustól távolságtartóan elhúzódó attitűdje is hozzájárult, sőt az is, hogy a fenomenológiai filozófia műveiben fellelhető kritikája is külön tónust kapott azért, mert a tapasztalatszerzés direkt irányzataihoz képest a műveiben föllelhető történeti és társadalmi dimenziók (amihez „az ember halála” értelmezések bírálata, avagy az emberi „szubjektivitás” fogalomértelmezése és erkölcsi komponensei) is közvetlen módon kísérték el a kormányzás mint jelenség, vagy a biopolitika mint erkölcsi aspektus kiemelt szemléletéhez. A Foucault-kritika emiatti átváltozása a hatvanas-hetvenes évektől napjainkig (a kritikai-politikai vitakérdésektől a kritikai-elemző szempontok felé közeledésben) mintegy új korszakot formál, immár nem egy „tan”, hanem egy társadalomelméleti-történeti álláspontként lett olyan elméleti keretté, amely a kultúra és a társadalom viszonyában áthatja az újabb filozófiai vizsgálódást egyfajta „diagnosztikai tevékenység” érdemi vállalásával, a múltból fakadó jelen megkülönböztető értékelésében vagy megfigyelésében. „A jelen diagnózisa tehát mindenekelőtt azt jelenti, hogy egyes jelenleg nagy súllyal érvényesülő társadalmi alakzatokat történeti származásuk alapján tárjuk fel. Mint láttuk, ennek szellemében szentelt Foucault elmélyült, és gyakran széttartó kutatásokat a tudás, a hatalom, a szubjektivitás modern jelenségeinek vizsgálatára" (Takács 2018: 176). S ehhez mind a kormányzás, a gondolkodásmódok, az 


\section{RECENZIÓ}

államérdek, a politikai önmegvalósítás 18. századi eredőitől az állammal szembeni ellenállás aktuális feladataiig, „az önmaguk kormányzására képes, modern egyének születési pillanatáról" is olyan fontos ontológiai belátásokat nyújt, amelyek terminológiája áthatotta az angolszász és francia, történeti és társadalomtudományi gondolkodást, új törésvonalak észrevétetésében is segít, valamint „a jelen diagnózisának programjával" újra és újra a mozgósítható filozófiai, tudományos és morális elemzés lehetőségét kínálja fel. Szemléletmódját lehet persze bírálni (mint Habermas tette módszertani kritikájával), de hogy „megfeledkezni” róla (mint Baudrillard javasolta) semmiképp sem lehet, az ma már nem szorul bizonygatásra. „Foucault aktualitását minden jel szerint az adja, hogy saját jelenünk tartogat alapvető meglepetéseket számunkra" (Takács 2018: 178).

A két kötet „egybeolvasása” nem szokványos megoldás - itt azonban nemcsak a társadalomtudományok felé szóló, a kritikai olvasatból fakadó „üzenet” a lényeges elem, hanem ez örökség hasznavehetőségének kérdései is eltérő értelmezési horizontot igényelnek és sugallanak. Az, hogy az életmű egésze, s az abból kihangzó „alkalmazott" ismeretek miképpen követelnek többet, mint szimpla idézetek tömegét, talán fölsejlik abból is, hogy a filozófián túli, a nyelvi és kommunikatív szféra intézményes közegébe vetett Foucault „távollévő nyoma” önmagát hitelesíti a történések rendjének sajátlagos szemléletével, a megnevezéssel, a filozófia feladatai között a nevesítő, nomináló eljárásmód szimbolizációs eszközként használatával is, melyekkel olyan értékelvű aspektust kínál, ami a reprezentáció elméletének megléte/hiánya mentén a lehetséges diskurzus elméletét teszi megismerés-elmélet alapjává, az „antropológiai szendergés” eszközök és értékek generálásában önérdekét kiteljesítő politikai cselekvésterévé, a szimbolikus politika cselekvő, attraktív, beavatkozó, reálpolitikai hatásának dramaturgiai fegyvertárba illeszkedő ontológiai státuszává. Ekképpen amiként megképződik maga az értelmezés univerzuma, jelentéstere vagy térbeli kiterjedése, annak éppen a birodalmias erőfölénybe átalakulni kész társadalmi törekvések (vö. jelenkortörténet) korunkbeli feladatai között van jelentősége. Foucault látszólag inkább csak kérdez, rákérdez, átfogalmaz, kételyeket szorgalmaz, újragondolást serkent. De válaszai mégis vannak.

Foucault még Foucault után is az marad, akit megkerülni, „feledni”, fölülírni nem lehet, s nem is érdemes. Jelenlétének hiánya a hiány jelenével hordozza az önértelmező olvasatok életművével egybeértendő teljességét, melyhez már a művek hatásreményét is előlegző bizonyosságkeresés is tartozik. 


\section{RECENZIÓ}

\section{Irodalom}

Baudrillard, J. (1977): Oublier Foucault. Galilée, Paris.

Derrida, J. (1978): Cogito and the history of madness. In Writing and Difference. The University of Chicago Press, Chicago.

Deleuze, G. (1986): Foucault. Les Éditions de Minuit, Paris.

Deleuze, G. (1989): Michel Foucault philosophe, Rencontre Internationale, Paris, 9, 10, 11 Janvier 1988. Éditions du Seuil, Paris.

Foucault, M. (1975, 1990): Surveiller et punir. Naissance de la prison. Éditions Gallimard, Paris. (Magyarul: Felügyelet és büntetés. A börtön története. Gondolat Kiadó, Budapest.)

Habermas, J. (1986): Taking Aim at the Heart of the Present. In Hoy, D. (eds): Foucault: A critical reader. Basil Blackwell. Oxford.

Kriegel, B. (2007): Michel Foucault ma. Fordította: Romhányi Török Gábor. Holnap Kiadó, Budapest. (Eredetileg Michel Foucault aujourd'hui. Plon, Paris, 2004.)

Kiss B. (1994): Michel Foucault hatalomfelfogásáról. Politikatudományi Szemle 3(1): 43-68.

Kiss B. (1997): Foucault még Foucault előtt. MTA Politikai Tudományok Intézete Politikatudományi múhelytanulmányok sorozat, Budapest.

Szakolczai Á. (1990): A fejlődés megkérdőjelezése. Akadémiai Kiadó, Budapest.

Szakolczay Á. (szerk.) (1991): A modernség politikai filozófiai dilemmái, a felvilágosodáson innen és túl. MTA Szociológiai Kutató Intézete, Budapest.

Takács Á. (2018) Az idő nyomai. Michel Foucault és a történelem problémája. Kijárat Kiadó, Budapest.

Zizek, S. (2007): Cogito, Madness and Religion: Derrida, Foucault and then Lacan. https://www.lacan.com/zizforest.html (Utolsó letöltés: 2020. 07.15.) 